\title{
Toward a COVID-19 testing policy: where and how to test when the purpose is to isolate
}

\section{silent spreaders}

$7 \quad{ }^{1}$ Center for Global Health, Department of Internal Medicine, Medical School, University of New

8 Mexico, Albuquerque, New Mexico, United States of America;

$9{ }^{2}$ Human Ecology, Centro de Investigación y de Estudios Avanzados (CINVESTAV), Mérida,

10 México;

$11{ }^{3}$ Department of Psychology, College of Charleston, Charleston, South Carolina, United States of

12 America;

$13{ }^{4}$ University of Vienna, Austria; and Higher School of Biotechnology, University of Strasbourg,

14 France \& French National Research Center (CNRS), France;

$15{ }^{5}$ Loyola University Chicago, Stritch School of Medicine, Chicago, IL, USA

$16{ }^{6}$ European University, Cyprus;

$17 \quad{ }^{7}$ Stremble Ventures LTD, Limassol, Cyprus;

$18{ }^{8}$ Department of Nursing, Faculty of Health Sciences University of Peloponnese, Tripoli, Greece;

$19{ }^{9}$ Food and Agriculture Organization, Dar es Salam, Tanzania \& Veterinary Tropical Diseases,

20 University of Pretoria. 


\section{Research in context}

\section{Evidence before this study}

25 To map this field, bibliographic searches were conducted in the Web of Science, which included

26 the following results: (i) COVID-19 (95,133 hits), (ii) SARS COV-2 (33,680 hits), (iii) testing

27 policy and COVID-19 (939 hits), (iv) testing policy and SARS COV-2 (340 hits), (v) testing

28 policy and COVID-19 and asymptomatic (80 hits), (vi) testing policy and SARS COV-2 and

29 asymptomatic (54 hits); (vii) test positivity and COVID-19 and validation (7 hits), and (viii) test

30 positivity and SARS CoV-2 and validation (5 hits). Therefore, before this study, testing policy in

31 relation to asymptomatic cases as well as test positivity represented a very low proportion

32 (between $\sim 1$ thousandth to $\sim 1$ ten thousandth) of all publications. While many articles

33 distinguished between diagnostic and screening tests, no paper was found in which testing policy

34 is mentioned as part of a process ultimately designed to isolate all infected individuals. The few

35 articles that mentioned test positivity only investigated symptomatic cases. These

36 quanti/qualitative assessments led the authors to infer that neither testing policy nor test

37 positivity had been adequately validated and/or investigated.

39 Added value of this study

40 We provide the first validation of test positivity as an estimate of disease prevalence under

41 rapidly changing conditions: in pandemics, disease prevalence may vary markedly within short

42 periods of time. We also address a double limitation of control campaigns against COVID-19,

43 namely: it is unknown who and where to test. Asymptomatic cases are not likely to seek medical

44 assistance: while they feel well, they silently spread this pandemic. Because they represent

45 approximately half of all infected individuals, they are a large, moving, and invisible target. 
medRxiv preprint doi: https://doi.org/10.1101/2020.12.22.20223651; this version posted December 24, 2020. The copyright holder for this preprint (which was not certified by peer review) is the author/funder, who has granted medRxiv a license to display the preprint in perpetuity.

It is made available under a CC-BY-NC-ND 4.0 International license.

46 Where to find them is also unknown because (i) randomized testing is likely to fail and (ii)

47 testing is very limited. Usually, the locations where infected people reside are not randomly

48 distributed but geographically clustered, and, up to now less than four persons per thousand

49 inhabitants are tested on a given day. However, by combining geo-referenced test positivity data

50 with cost-benefit considerations, we generate approaches not only likely to induce high benefits

51 without increasing costs but also free of assumptions: we measure bio-geography as it is.

53 Implications of all the available evidence

54 The fact that asymptomatic cases were not tested in many countries may explain the exponential

55 growth and much higher number of deaths observed in those countries. Ineffective testing (and,

56 therefore, ineffective isolation) can also result from the absence of geo-referenced data analysis.

57 Because the geographical location where people reside, work, study, or shop is not a random

58 event, the analysis of small greographical areas is essential. Only when actual geographical

59 relationships are observed, optimal (cost-benefit oriented) testing policies can be devised.

60 
medRxiv preprint doi: https://doi.org/10.1101/2020.12.22.20223651; this version posted December 24, 2020. The copyright holder for this preprint (which was not certified by peer review) is the author/funder, who has granted medRxiv a license to display the preprint in perpetuity.

It is made available under a CC-BY-NC-ND 4.0 International license .

\section{Summary}

62 Background To stop pandemics, such as COVID-19, infected individuals should be detected,

63 treated if needed, and -to prevent contacts with susceptible individuals- isolated. Because most

64 infected individuals may be asymptomatic, when testing misses such cases, epidemics may

65 growth exponentially, inducing a high number of deaths. In contrast, a relatively low number of

66 COVID-19 related deaths may occur when both symptomatic and asymptomatic cases are tested.

67 Methods To evaluate these hypotheses, a method composed of three elements was evaluated,

68 which included: (i) county- and country-level geo-referenced data, (ii) cost-benefit related

69 considerations, and (iii) temporal data on mortality or test positivity (TP). TP is the percentage of

70 infections found among tested individuals. Temporal TP data were compared to the tests/case

71 ratio (T/C ratio) as well as the number of tests performed/million inhabitants (tests/mi) and

72 COVID-19 related deaths/million inhabitants (deaths/mi).

73 Findings Two temporal TP profiles were distinguished, which, early, displayed low ( $1 \%)$

74 and/or decreasing TP percentages or the opposite pattern, respectively. Countries that exhibited

$75>10 \mathrm{TP} \%$ expressed at least ten times more COVID-19 related deaths/mi than low TP countries.

76 An intermediate pattern was identified when the T/C ratio was explored. Geo-referenced, TP-

77 based analysis discovered municipalities where selective testing would be more cost-effective

78 than alternatives.

79 Interpretations When $\mathrm{TP}$ is low and/or the $\mathrm{T} / \mathrm{C}$ ratio is high, testing detects asymptomatic

80 cases and the number of COVID-19 related deaths/mi is low. Geo-referenced TP data can

81 support cost-effective, site-specific policies. TP promotes the prompt cessation of epidemics and

82 fosters science-based testing policies.

83 Funding None 
medRxiv preprint doi: https://doi.org/10.1101/2020.12.22.20223651; this version posted December $24,2020$. The copyright holder for this

It is made available under a CC-BY-NC-ND 4.0 International license .

\section{Introduction}

85 Albert Bartlett partially dedicated his life to teaching the expressions and consequences

86 of the exponential function [1]. Epidemics -including the COVID-19 pandemic- tend to grow or

87 decline exponentially. Given the catastrophic consequences of the epidemic exponential growth

88 [2 Rudan ], the first priority in epidemic control is to avoid contacts: when it takes just 60 days to

89 increase from 1 to $>60,000$ COVID-19 related deaths (as observed in this pandemic),

90 'coexistence with the virus' or 'flattening the epidemic curve' is not a likely outcome.

91 Because blocking contacts between infected and susceptible individuals prevents the

92 exponential growth of an epidemic, testing is the first priority of a control policy: it allows to

93 detect, treat if needed, and isolate all infected individuals. Hence, the WHO summarizes its

94 recommendations with three words: test, treat, isolate [3].

95 However, a substantial proportion of individuals infected with SARS CoV-2 may be

96 infectious even without symptoms. Hence, identifying asymptomatic cases is a crucial element in

97 epidemic control: if they were rapidly identified and subsequently isolated, the virus could be

98 removed from the environment and the pandemic would stop [4-7]. The theoretical solution for

99 this problem is to test every inhabitant of every country.

100 Unfortunately, massive testing (the type required to identify all infected individuals) is

101 not currently feasible in most countries. This situation creates a new challenge: how can major

102 disseminators of the COVID-19 pandemic be identified when testing is limited (or very limited)?

103 Therefore, a fourth action should be added to the three proposed by WHO: identification.

104 The determination of the geographical sites where asymptomatic cases are likely to be located is

105 the linchpin of epidemic control. However, only a minor proportion of the population is tested on

106 a given day (usually less than four per thousand inhabitants [8]). Given the scarce resources 
107 available, the limited testing, and the need to remove viral spreaders before the epidemic

108 exponential growth overwhelms the anti-epidemic responses, identification should be precise,

109 rapidly implemented, and cost-effective [9-11]. To address this composite problem, new metrics

110 and methods may be required.

111 Test positivity (TP) is a concept to be considered. TP is the percentage of infections

112 detected among tested individuals. While TP has been used for more than seven decades, in the

113 context of COVID-19 it was first mentioned on March 30, 2020, by WHO [12]. Classically, TP

114 has been utilized in reference to the ability of a test to identify and distinguish infection-positive

115 from infection-negative individuals (also known as sensitivity and specificity, when the inference

116 refers to the past; or test positive/negative predictive value, when the inference refers to the

117 future). Such tests have a diagnostic purpose. They differ from screening tests [7, 13].

118 In this report, TP is viewed as a metric that may evaluate the efficacy of testing programs

119 aimed at detecting asymptomatic COVID-19 cases; i.e., test positivity percentages may indirectly

120 help to elucidate whether testing is or is not capturing asymptomatic cases, even when the

121 number of tests performed per million inhabitants is low. In this context, TP is a component of

122 an epidemiologic strategy used in a rapidly changing environment with the purpose of detecting

123 and isolating infected individuals before the epidemic exponential process consolidates.

124 To the best of our knowledge, the validity of the TP metric to detect asymptomatic cases

125 when testing is limited has not yet been demonstrated. To understand why TP percentages may

126 achieve that goal, the history of epidemics is worth revisiting. When disease prevalence is zero

127 (before an epidemic starts), the TP \% is zero, too. The TP $\%$ is expected to be non-zero (but

128 relatively low) after epidemic onset. That is so because even the worst epidemics on record have

129 infected only a minor percentage of the population -for instance, the highest estimates on 
130 fatalities induced by the 1918 flu pandemic are about 5\% [14].

131 Accordingly, when the TP \% approaches or exceeds 50\% (as reported in several countries

132 affected by COVID-19), it is unlikely that such numbers reflect the actual disease prevalence.

133 Instead, high TP percentages may express testing conducted within a subpopulation that does not

134 (or only marginally) promote(s) epidemic spread: the group of symptomatic cases. Because

135 symptomatic cases are easily detected, they are also easily treated and isolated. Consequently,

136 symptomatic cases are not likely to disseminate epidemics. In contrast, infected but undetected

137 individuals -asymptomatic cases- transmit the disease [15].

138 Therefore, high TP percentages may be observed when the testing policy predominantly

139 detects symptomatic cases (as explicitly pursued by official policies or promoted by research

140 institutions of some countries [16-18]). This hypothesis is further supported when the alternative

141 is associated with promising outcomes, that is, when lower TP values are found in countries

142 where the testing policy explicitly captures asymptomatic cases and, later, much fewer deaths per

143 million inhabitants are reported than in countries reporting high TP percentages. This means that

144 low TP percentages may reflect the prompt removal of SARS CoV-2-positive individuals -a

145 likely outcome of policies that test asymptomatic cases. Thus, empirically elucidating whether

146 high TP percentages are found when asymptomatic cases are excluded in the testing policy as

147 well as the alternative hypothesis -low TP percentages are associated with testing programs

148 that detect asymptomatic cases-are pre-requisites of scientifically sound testing policies meant

149 to identify and isolate the spreaders of epidemics.

150 Other metrics of potential interest include: (i) the number of new cases, (ii) the number

151 of COVID-19 related deaths/million inhabitants (deaths/mi), and (iii) the ratio between the

152 number of tests and the number of cases detected (the $\mathrm{T} / \mathrm{C}$ ratio). The time when the highest 
medRxiv preprint doi: https://doi.org/10.1101/2020.12.22.20223651; this version posted December $24,2020$. The copyright holder for this preprint (which was not certified by peer review) is the author/funder, who has granted medRxiv a license to display the preprint in perpetuity.

It is made available under a CC-BY-NC-ND 4.0 International license .

153 number of new cases occur is a relevant input of epidemiologic decision-making [19]. Because

154 testing policies that only emphasize symptomatic cases will generate biased estimates on when

155 new cases peak, approaches that detect asymptomatic cases are needed [16].

156 To demonstrate that novel testing methods can capture asymptomatic cases even when

157 testing is limited, high-resolution, geo-referenced data may be required. When small

158 geographical areas report high TP percentages, intensive testing in such areas could induce

159 benefits that will include the larger surrounding area, generating high benefit-cost ratios [20].

160 Accordingly, relationships between the TP percentage, its inverse (the number of tests

161 conducted per each detected case ratio or T/C ratio), and other metrics (the number of new cases

162 and the number of deaths per million inhabitants) were investigated across countries and -using

163 geo-referenced data of high resolution - across municipalities. This study aimed at elucidating

164 whether, when and where the TP percentage and/or the T/C ratio informed earlier and/or

165 provided more information than classic metrics in reference to asymptomatic cases and, if so

166 demonstrated, whether such metrics, once geo-referenced, could foster region-specific, cost-

167 benefit oriented control policies.

168

169 Materials and methods

170 Methods

171 Data on new (daily) tests performed, cases identified, test positivity (the percentage of positive

172 cases/tests performed) and its inverse (the test/case ratio), as well as the cumulative number of

173 tests or deaths per million inhabitants were collected from publicily available data sources and

174 compared across countries and across time. Countries were classified as either displaying high or

175 low test positivity (TP) when, at least three months after the initiation of the epidemic, they 
medRxiv preprint doi: https://doi.org/10.1101/2020.12.22.20223651; this version posted December 24, 2020. The copyright holder for this preprint (which was not certified by peer review) is the author/funder, who has granted medRxiv a license to display the preprint in perpetuity.

It is made available under a CC-BY-NC-ND 4.0 International license .

176 showed non-overlapping intervals of TP and such classes also revealed non-overlapping intervals

177 of epidemic-related outcomes (deaths/million inhabitants). Differences in median deaths/million

178 inhabitants between low TP and high TP countries were investigated with the Mann-Whitney test

179 using a commercial statistical package (Minitab LLC, State College, PA, USA). Geographical

180 data were processed with ARC GIS software (ESRI, Redlands, Ca, USA). Thirteen countries

181 were evaluated because, together, they exhibited geographical and demographic diversity and

182 individually, they were affected by COVID-19 long enough (two or more months) so they could

183 reveal exponential epidemic growth, if it happened. Such countries were: Bangladesh, Belgium,

184 Colombia, Cyprus, Ethiopia, Germany, Greece, Italy, South Africa, South Korea, Spain,

185 Uruguay, and the United States. To explore georeferenced data on test positivity, the

186 municipality-specific data reported by Harvard University on Puerto Rico were analyzed

187 [https://rconnect.dfci.harvard.edu/covidpr/?s=08]. Because many countries have reported errors

188 and/or changed the definition of cases and deaths and because not all affected countries were

189 investigated, inferences should not be construed to be representative. However, inferences

190 derived from patterns observed in two or more countries (or regions of a country) may be viewed

191 as plausible and, possibly, generalizable.

192

193 Data

194 Data were extracted from Worldometer and/or governmental sites (

195 https://www.worldometers.info/coronavirus/; https://www.pio.gov.cy/coronavirus/eng ;

196 https://eody.gov.gr/epidimiologika-statistika-dedomena/ektheseis-covid-19/;

197 https://www.gub.uy/sistema-nacional-emergencias/). 


\section{Results}

$\underline{\text { Test positivity-related temporal patterns }}$

Findings revealed two temporal patterns: (i) one characterized by an early TP peak (the highest TP percentages took place in the first weeks), followed by a rapid decline to $\sim 1 \%$ (four countries, green rectangles, Figs. 1 A-D); and (ii) a pattern shared by six countries, which showed later and increasing TP values, even $>10 \%$, over one or more weeks (red rectangles, Figs. 1 E-J). In addition, the data of ten countries consistently demonstrated that the highest TP percentages occurred earlier or at the same time as, but not later than the number of new cases (Fig. 1 A-J). The first pattern (low TP percentage) was associated with a quasi-complete cessation of the epidemic within four months. The second pattern (high TP percentages) was shown by countries where, four to six months into the epidemic, the median number of deaths/mi was at least 10 times higher than in countries displaying the alternative pattern $(p<0.02$, Fig. 2$)$.

\section{Validation of TP-based testing policies designed to detect asymptomatic cases}

Four-dimensional (3D and temporal) plots that included TP percentages and T/C ratios identified three profiles, characterized by: (i) high TP percentages (data points shown only in the upper right quadrant, 4 countries); (ii) a hybrid pattern, which exhibited high TP and some high $\mathrm{T} / \mathrm{C}$ observations (one country); and (iii) countries predominantly displaying high $\mathrm{T} / \mathrm{C}$ ratio values (four countries, Figs. 3 A-I). TP values less than $5 \%$ did not predict the end of the epidemic -even countries displaying $<1 \% \mathrm{TP}$ over more than two weeks failed to report zero cases after such a period of time (Figs. 4 A-D). 
medRxiv preprint doi: https://doi.org/10.1101/2020.12.22.20223651; this version posted December $24,2020$. The copyright holder for this preprint (which was not certified by peer review) is the author/funder, who has granted medRxiv a license to display the preprint in perpetuity.

It is made available under a CC-BY-NC-ND 4.0 International license .

To investigate the hypothesis that geo-referenced and temporal TP data support site-

223 specific, cost-effective interventions, the test positivity percentages reported in all municipalities

224 of Puerto Rico on September 11, 2020, were investigated. One municipality reported a TP

$225>50 \%$, which was surrounded by 17 municipalities that reported much lower TPs. Assuming that

226 testing resources (including tests) were distributed according to the size of the population, the

227 municipality with $>50 \%$ TP received $1 / 42$ of such resources and the remaining municipalities

228 obtained testing-related resources 42 times larger in magnitude (Fig. 5).

229 Such a situation facilitated cost-benefit oriented, geographically and epidemiologically

230 specific interventions. For instance, if the level of testing implemented in area 1 (the

231 municipality with $>50 \%$ TP) was decided to be increased $1000 \%$, immediately -but no new

232 resources were provided-, the additional tests required in area 1 could only come from area 2.

233 This means that 10 of the original 43 units of resources spent in areas 1 and 2 (1 unit spent in

234 area 1 and 42 units spent in area 2) would now be used in area 1 (a 1000\% increase). This

235 solution would cause a $23.56 \%$ reduction (from 42 to 32 ) in the units of resources spent in area 2

236 - a region barely affected by the epidemic and, therefore, highly vulnerable (Fig. 5).

237 These data also estimated the costs of random testing and/or testing that ignores geo-

238 temporal cost-benefit considerations. If the surrounding area (area 2) was affected as much as

239 area 1, the size of epidemic could increase 42 times (Fig. 5). This epidemic growth could occur

240 even if testing continued, uninterruptedly, at the same level as previously performed.

$242 \quad \underline{\text { Additional tools }}$

243 Relationships between metrics elucidated when testing was or was not adequate.

244 Examples collected from 14 countries revealed when testing grew faster than cases (a desirable 
medRxiv preprint doi: https://doi.org/10.1101/2020.12.22.20223651; this version posted December $24,2020$. The copyright holder for this preprint (which was not certified by peer review) is the author/funder, who has granted medRxiv a license to display the preprint in perpetuity.

It is made available under a CC-BY-NC-ND 4.0 International license .

245 outcome) or the alternative pattern suggested additional testing was needed (Fig. 6A-D). The use

246 of the number of deaths per million inhabitants was also informative (Figs. 6 E-H).

248 Discussion

249 Because asymptomatic patients rarely request medical assistance, they may become the

250 invisible spreaders of epidemics. Consequently, testing, treating, and isolating such cases should

251 be prioritized [3]. However, given that testing is usually limited, their identification is

252 problematic [8]. This compounded problem was addressed with an approach that, considering

253 test positivity (TP), evaluated testing policies that prioritize the detection of asymptomatic cases

254 and also considers geo-referenced, cost-benefit oriented data analysis.

255 Testing symptomatic or asymptomatic cases may depend on medical and public health-

256 related perspectives [7]. For instance, testing that emphasizes symptomatic cases differs from

257 screening-oriented testing. In the first case, it is assumed that epidemics can be stopped through

258 interventions conducted within hospitals -as when individuals that feel ill seek medical

259 assistance. It is expected to find high percentages of test positivity when confirmatory testing is

260 promoted (the type of testing physicians are likely to prescribe). While this type of testing (or

261 purpose) is necessary when a clinical perspective is considered, it does not contribute much to

262 prevent epidemic spread, which depends on early detection of asymptomatic cases $[7,18]$. In

263 contrast, in population medicine, epidemiologic testing is needed (screening or information

264 usable in epidemic control, not only in clinical medicine). Here it was hypothesized that lower

265 TP percentages predicted lower numbers of deaths per million inhabitants than when higher TP

266 percentages were observed -findings consistent with the hypothesis that asymptomatic cases are

267 detected when the percentage of TP is low. Findings supported these hypotheses, opening a path 
toward scientifically grounded testing policies that seek to detect (and immediately isolate)

269 asymptomatic -not only symptomatic- cases [7, 18]. As expected, countries that displayed high

270 TP percentages in early epidemic stages, later reported many more deaths/mi than low TP

271 countries. These findings supported the notion that, in high TP countries, asymptomatic cases

272 were missed and, consequently, the epidemic grew exponentially and so did deaths.

273 The epidemics here investigated also showed that TP peaks occur earlier than the peak

274 number of new cases. Data turning points (which include peaks) help to conduct epidemiologic

275 forecasts [21].

276 Findings also addressed the statement made by WHO on May 12, 2020, which suggested

277 that low $(<5 \%)$ TP values over two consecutive weeks signal that an epidemic is under control

278 [22]. This study found that even 1\% TP was associated with longer epidemics (Figs. 3 A-D).

The fact that neither a $5 \%$ nor a $1 \%$ TP cutoff predicted the immediate cessation of an

280 epidemic was expected: dichotomization of continuous data promotes errors. Such a procedure

281 assumes that the discrete (discontinuous) nature of a process can change below or above a cutoff

282 generated by continuous data. Yet, the evidence demonstrated that an 'epidemic-positive'

283 country does not become an 'epidemic-negative' one when TP changes from 5.00 to $4.99 \%$.

284 While pattern recognition can discriminates without numerical cutoffs (as Fig. 5 shows), the

285 dichotomization assumption tends to lose information and generates errors [23].

Therefore, TP seems a robust and explanatory metric. Unlike the number of new cases,

287 TP may inform when (and, provided that geo-referenced information is also available, where)

288 spikes of its percentage will identify specific places that require additional testing so

289 asymptomatic cases can be rapidly detected, isolated, and treated [24]. However, to prevent such

290 patients from promoting exponential epidemic growth, early and geographically-specific 
291 responses are needed. Here, an operational model showed that observable geo-epidemiologic

292 features can generate site-specific, cost-effective interventions.

293 Investigating geo-referenced epidemiologic data matters because humans are not

294 homogeneously distributed in space. Lakes, railroads, schools and many other (geographically

295 specific) entities both separate and connect humans. While some geographical points act as

296 epidemic nodes, many points do not seem to influence epidemic spread [25].

While earlier studies have conducted cost-benefit analysis of COVID-19 control policies,

298 they lacked geo-referenced data [26]. The geo-referenced, cost-benefit theory followed in this

299 study assumed that epidemics disseminate as floods do: from a 'higher' point (where disease

300 prevalence or its surrogate, test positivity, is higher) toward surrounding areas where test

301 positivity percentages are lower. When cost-benefit oriented interventions are not immediately

302 implemented in such situations, the epidemiologic condition of the surrounding region can

303 rapidly worsen. This epidemiologic 'flood' metaphor was empirically supported: rapid

304 interventions in small areas that threaten larger areas tend to be highly cost-effective and may

305 stop epidemics (Fig. 4).

306 While aggregate (state- or country- level) data do not reveal spatial relationships and,

307 therefore, are not very useful [27], non-aggregate geo-referenced information -e.g., data on

308 neighborhoods- are epidemiologically usable, as shown with municipality-level information

309 collected in Puerto Rico (Fig. 5). When geographical-epidemiological relationships are

310 considered, it is possible to identify policies that benefit not only the area of direct intervention

311 but also the surrounding area -as commonly practiced in flood protection-related policies [28].

312 This approach has also been described as the 'wrong pocket problem', i.e., the area where the

313 investment is made does not only benefit from it: a larger area is benefited as well [29]. One 
medRxiv preprint doi: https://doi.org/10.1101/2020.12.22.20223651; this version posted December 24, 2020. The copyright holder for this preprint (which was not certified by peer review) is the author/funder, who has granted medRxiv a license to display the preprint in perpetuity.

It is made available under a CC-BY-NC-ND 4.0 International license .

314 example of this geographically grounded, cost-benefit oriented approach has recently been

315 applied in an emergency vaccination against rabies conducted in Tanzania, where a limited

316 intervention in a small ring that surrounded a large city also benefitted the large city [11].

317 Findings support the view that, to stop epidemic exponential growth, testing policies should

318 aim at detecting all infected individuals (including asymptomatic cases). In spite of its relevance,

319 testing policy seems an area that lacks interdisciplinary scientific expertise. Approaches that

320 include temporal and geo-referenced test positivity data, as well as cost-benefit oriented

321 considerations, may contribute toward filling that gap.

322

\section{Contributors}

324 All authors contributed to model design, interpretation of results, and writing of the report. ALR,

325 ALH, AI, AA and PV collected data. JBH and FOF transcribed and analyzed the data. JLF made

326 maps, ALR and MHVvR drafted the manuscript.

328 Declaration of interests

329 We declare no competing interests.

\section{Data sharing}

332 No primary data were collected for this study, which used publicly available data. The sources of

333 the data used are described in this article.

\section{Funding}

336 No funding was received from any agency in the commercial or non-profit sectors. 
medRxiv preprint doi: https://doi.org/10.1101/2020.12.22.20223651; this version posted December 24, 2020. The copyright holder for this preprint (which was not certified by peer review) is the author/funder, who has granted medRxiv a license to display the preprint in perpetuity.

It is made available under a CC-BY-NC-ND 4.0 International license .

\section{References}

339 1. Arithmetic, Population and Energy - a talk by Al Bartlett.

340 https://www.albartlett.org/presentations/arithmetic_population_energy_video1.html

$341 \quad \underline{(\text { accessed Dec 5, 2020) }}$

342 2. Rudan I. A cascade of causes that led to the COVID-19 tragedy in Italy and in other

343 European Union countries. J Glob Health 2020; 10: 010335.

$344 \quad$ https://doi.org/10.7189/jogh.10.010335

345 3. World Health Organization. WHO coronavirus briefing: Isolation, testing and tracing

346 comprise the 'backbone' of response. https://www.weforum.org/agenda/2020/03/testing-

$347 \quad$ tracing-backbone-who-coronavirus-wednesdays-briefing/ (accessed Dec 5, 2020)

348 4. Anderson RM, Heesterbeek H, Klinkenberg D, Hollingsworth TD. How will country-based

349 mitigation measures influence the course of the COVID-19 epidemic? Lancet 2020; 395:

350 931-934. https://doi.org/10.1016/S0140-6736(20)30567-5

351 5. Gandhi M, Yokoe DS, Havlir DV. Asymptomatic transmission, the Achilles' Heel of

352 current strategies to control COVID-19. N Engl J Med 2020; 382: 2158-2160.

$353 \quad$ https://doi.org/10.1056/NEJMe2009758.

354 6. Han MS, Choi EH, Chang SH, et al. Clinical characteristics and viral RNA detection in

355 children with coronavirus disease 2019 in the Republic of Korea. JAMA Pediatr 2020;

356 Published online August 21. https://doi.org/10.1001/jamapediatrics.2020.3988

357 7. Raffle AE, Pollock AM, Harding-Edgar L. Covid-19 mass testing programmes. BMJ 2020;

358 370: $\mathrm{m} 3262$. http://dx.doi.org/10.1136/bmj.m3262

359 8. Ourworldindata. Coronavirus (COVID-19) Testing. https://ourworldindata.org/coronavirus-

$360 \quad$ testing (accessed Oct 28, 2020) 
medRxiv preprint doi: https://doi.org/10.1101/2020.12.22.20223651; this version posted December 24,2020 . The copyright holder for this preprint (which was not certified by peer review) is the author/funder, who has granted medRxiv a license to display the preprint in perpetuity.

It is made available under a CC-BY-NC-ND 4.0 International license .

361 9. Rivas AL, Tennenbaum SE, Aparicio JP, et al. Critical response time (time available to

362 implement effective measures for epidemic control): model building and evaluation. Can J

$363 \quad$ Vet Res 2003; 67: 307-311.

364 10. Rivas AL, Fasina FO, Hoogesteyn AL, et al. Connecting network properties of rapidly

365 disseminating epizoonotics. PLoS One 2012; 7: e39778.

366 https://doi.org/10.1371/journal.pone.00397782012

367 11. Fasina FO, Mtui-Malamsha N, Mahiti GR, et al. Where and when to vaccinate?

368 Interdisciplinary design and evaluation of the 2018 Tanzanian anti-rabies campaign. IJID

$369 \quad$ 2020; 95: 352-360. https://doi.org/10.1016/j.ijid.2020.03.037

370 12. World Health Organization. COVID-19-virtual press conference -30 March 2020.

371 https://www.who.int/docs/default-source/coronaviruse/transcripts/who-audio-emergencies-

372 coronavirus-press-conference-full-30mar2020.pdf?sfvrsn=6b68bc4a 2 (accessed July 20,

$3732020)$.

374 13. Speechley M, Kunnilathu A, Aluckal E, et al. Screening in Public Health and Clinical Care:

375 similarities and differences in definitions, types, and aims - a systematic review. JClin Diagnostic

376 Res 2017; 11: LE01-LE04.

377 https://doi.org/10.7860/JCDR/2017/24811.9419

378 14. Roser M. The Spanish flu (1918-20): The global impact of the largest influenza pandemic in

379 history. https://ourworldindata.org/spanish-flu-largest-influenza-pandemic-in-history

$380 \quad$ (accessed Sept 24, 2020).

381 15. Basnarkov L. SEAIR epidemic spreading model of COVID-19. arXiv:2005.11815v2

382 [physics.soc-ph] http://arxiv.org/abs/2005.11815v2

383 16. Iosa M, Paolucci S, Morone G. Covid-19: A dynamic analysis of fatality risk in Italy. Front. 
medRxiv preprint doi: https://doi.org/10.1101/2020.12.22.20223651; this version posted December 24, 2020. The copyright holder for this preprint (which was not certified by peer review) is the author/funder, who has granted medRxiv a license to display the preprint in perpetuity.

It is made available under a CC-BY-NC-ND 4.0 International license .

Med. 2020, 7: 185. https://doi.org/10.3389/fmed.2020.00185

385

17. Deutsche Welle. Germany's coronavirus response: Separating fact from fiction. https://www.dw.com/en/germanys-coronavirus-response-separating-fact-from-fiction/a$\underline{53053822}$ (accessed Dec 5, 2020).

18. Padula WV. Why only test symptomatic patients? Consider random screening for COVIDQ 19. Appl Health Econ Health Policy 2020; 18: 333-334. https://doi.org/10.1007/s40258-020-00579-4

391 19. Tsallis C, Tirnakli U. Predicting COVID-19 peaks around the world. Front Phys 2020; 8: 217 . https://doi.org/10.3389/fphy.2020.00217

20. Rivas AL, Hoogesteijn AL, Hittner JB, et al. Addressing a complicated problem: can

394 COVID-19 asymptomatic cases be detected - and epidemics stopped- when testing is limited 395 and the location of such cases unknown? medRxiv preprint

$396 \quad$ https://doi.org/10.1101/2020.11.10.20223495

397 21. Liu Z, Magal P, Webb G. Predicting the number of reported and unreported cases for the 398 COVID-19 epidemics in China, South Korea, Italy, France, Germany and United Kingdom. 399 medRxiv preprint doi: $\underline{\text { https://doi.org/10.1101/2020.04.09.20058974 }}$

400 22. World Health Organization. Considerations for implementing and adjusting public health and 401 social measures in the context of COVID-19. https://www.who.int/publications/i/item/public402 health-criteria-to-adjust-public-health-and-social-measures-in-the-context-of-covid-19 403 (accessed: Sept 4, 2020).

404 23. Altman DG, Royston P. The cost of dichotomising continuous variables. BMJ 2006; 332:

405 1080. https://doi.org/10.1136/bmj.332.7549.1080

406 24. Machanick P. Revisiting early-stage COVID-19 strategy options [version 2; peer review: 
medRxiv preprint doi: https://doi.org/10.1101/2020.12.22.20223651; this version posted December 24, 2020. The copyright holder for this preprint (which was not certified by peer review) is the author/funder, who has granted medRxiv a license to display the preprint in perpetuity.

It is made available under a CC-BY-NC-ND 4.0 International license .

407

408

409

410

411

412

413

414

415

416

417

418

419

420

421

422

423

424

awaiting peer review] F1000 Research 2020, 9:327. https://doi.org/10.12688/f1000research.23524.2

25. Rivas AL, Febles JL, Smith SD, et al. 2020 Early network properties of the COVID-19 pandemic - the Chinese scenario. IJID 2020; 96: 519-523.

26. Reddy KP, Shebl KM, Foote JHA, et al. Cost-effectiveness of public health strategies for COVID-19 epidemic control in South Africa. Lancet Glob Health 2020; Nov 11:S2214109X(20)30452-6. https://doi.org/10.1016/S2214-109X(20)30452-6

27. Ortiz-Pelaez A, Pfeiffer DU, Soares-Magalhães RJ, Guitian FJ. Use of social network analysis to characterize the pattern of animal movements in the initial phases of the 2001 foot and mouth disease (FMD) epidemic in the UK. Prev Vet Med 2006; 76: 40-55. https://doi.org/10.1016/j.prevetmed.2006.04.007

28. Syrbe R-U, Walz U. Spatial indicators for the assessment of ecosystem services: Providing, benefiting and connecting areas and landscape metrics. Ecol Indic 2012; 21: 80-88. https://doi.org/10.1016/j.ecolind.2012.02.013

29. McCullough JM. Declines in spending despite positive returns on investment: understanding Public Health's Wrong Pocket Problem. Front Public Health 2019; 7: 159. https://doi.org/10.3389/fpubh.2019.00159 
medRxiv preprint doi: https://doi.org/10.1101/2020.12.22.20223651; this version posted December 24, 2020. The copyright holder for this preprint (which was not certified by peer review) is the author/funder, who has granted medRxiv a license to display the preprint in perpetuity.

It is made available under a CC-BY-NC-ND 4.0 International license .

\section{Figure legends}

426 Fig. 1. Temporal relationships between the test positivity percentage and the number of

427 new cases. Two epidemic patterns were differentiated among10 countries: (i) epidemics that

428 revealed a rapid decrease in the test positivity (TP) percentage and, subsequently, displayed very

429 low (<1\%) TP values (green rectangles, A-D); and (ii) epidemics that reported either later TP

430 peaks, increasing percentages of the TP over two or more weeks, and/or TP percentages higher

431 than 5\% (red rectangles, E-J). In all ten countries investigated, the peak TP percentage occurred

432 earlier than the peak number of new cases. Source: Worldometer.

434 Fig. 2. Temporal relationships between test positivity percentage and deaths per million

435 inhabitants. By August 25, 2020 (at least four months into the epidemic), the group of countries

436 that, earlier, reported high (three-digit) test positivity percentages (high TP) showed at least 10

437 times more deaths per million inhabitants $(\mathrm{d} / \mathrm{mi})$ than countries that, earlier displayed low (two-

438 digit) TP percentages ( $p<0.02$, Mann-Whitney test). High and low TP countries revealed non-

439 overlapping data intervals (rectangles). Source: Worldometer.

441 Fig. 3. Temporal relationships between test positivity and the tests/case ratio. The

442 assessment of the tests/case ratio revealed more information when nine countries were

443 investigated, which partially included the set reported in Fig. 1. Four countries showed high TP

444 percentages but few or no high tests/case ratios (A-D). One country displayed a hybrid pattern,

445 which was characterized by a few high TP percentages and a few high tests/case ratios (E). The

446 remaining four countries predominantly exhibited high tests/case ratios (F-I).

448 Fig. 4. Pattern- vs. threshold-based evaluations of epidemic control measures. Four 
medRxiv preprint doi: https://doi.org/10.1101/2020.12.22.20223651; this version posted December $24,2020$. The copyright holder for this preprint (which was not certified by peer review) is the author/funder, who has granted medRxiv a license to display the preprint in perpetuity.

It is made available under a CC-BY-NC-ND 4.0 International license .

449 countries located in three continents showed new cases even when the percentage of test

450 positivity (TP) was < $1 \%$ (ovals, A-D). Because new cases were observed over protracted (more

451 than two-week long) periods of time, it is concluded that no numerical cutoff (e.g., TP $<5 \%$ )

452 indicates an epidemic is under control. In contrast, patterns -such as a perpendicular data

453 inflection- promote inferences, regardless of any cutoff value.

455 Fig. 5. Geo-epidemiologically specific, cost-benefit effective, differential testing. The test

456 positivity (TP) percentages reported in all municipalities of Puerto Rico, on Sept 11, 2020, are

457 depicted. Area 1 shows the municipality of Jayuya. Area 2 identifies a larger, surrounding region

458 that includes $\sim 42$ times more people and covers an area $\sim 8.5$ times larger than those of Jayuya.

459 Given Jayuya $+50 \%$ TP, a greater testing effort conducted in this municipality may yield large

460 benefits, which may also include the surrounding area (Area 2) and, indirectly, benefit the

461 western half of the island. Vice versa, keeping the same level of testing performed before may

462 lead to long-lasting, costly consequences: if the virus circulating within Jayuya reached the

463 surrounding area and the prevalence of COVID-19 became similar to the one affecting Jayuya

464 (which is estimated by test positivity), then a much larger number of people (up to 42 times

465 larger) could become infected, who would reside in an area 8.5 times larger, i.e., control would

466 then be much harder, longer and costlier.

468 Fig. 6. Relationships between outcomes (non-fatal or fatal infections) and the number of

469 tests/million inhabitants. Testing policies may be adjusted based on patterns generated by

470 cases (A-D) and fatalities (E-H). When testing grows slower than cases or deaths (when the

471 curvature approaches a vertical pattern), testing is likely to be insufficient or inadequate. 
medRxiv preprint doi: https://doi.org/10.1101/2020.12.22.20223651; this version posted December 24, 2020. The copyright holder for this preprint (which was not certified by peer review) is the author/funder, who has granted medRxiv a license to display the preprint in perpetuity.

It is made available under a CC-BY-NC-ND 4.0 International license .

A

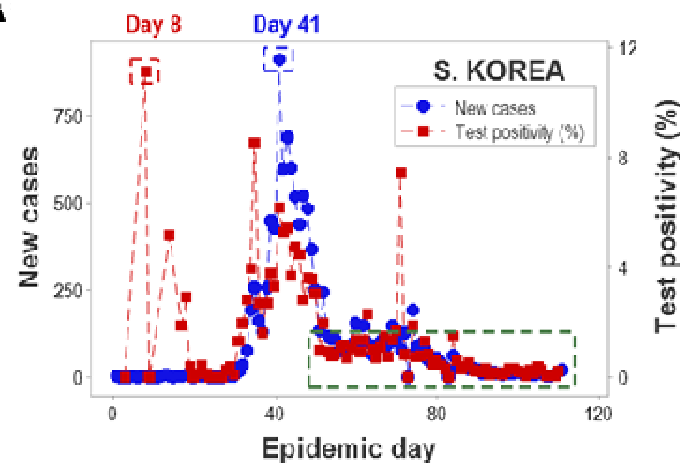

C

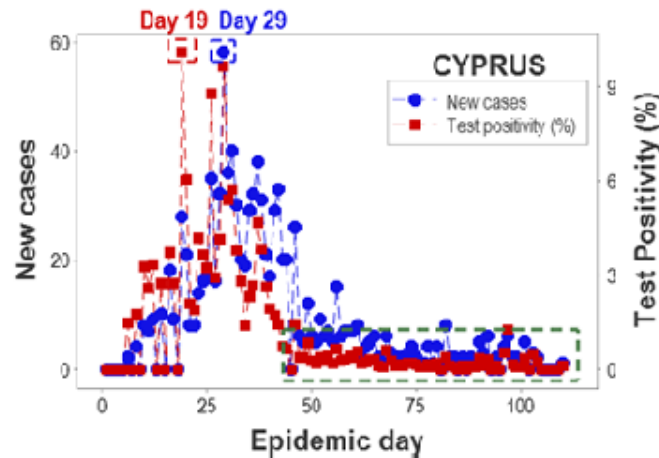

E

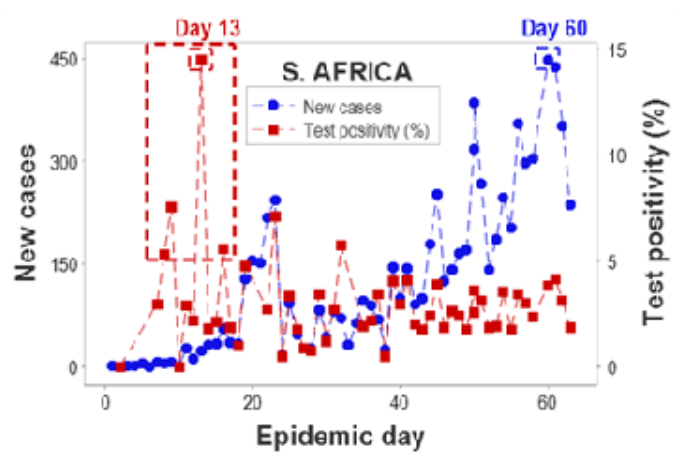

$\mathbf{0}$
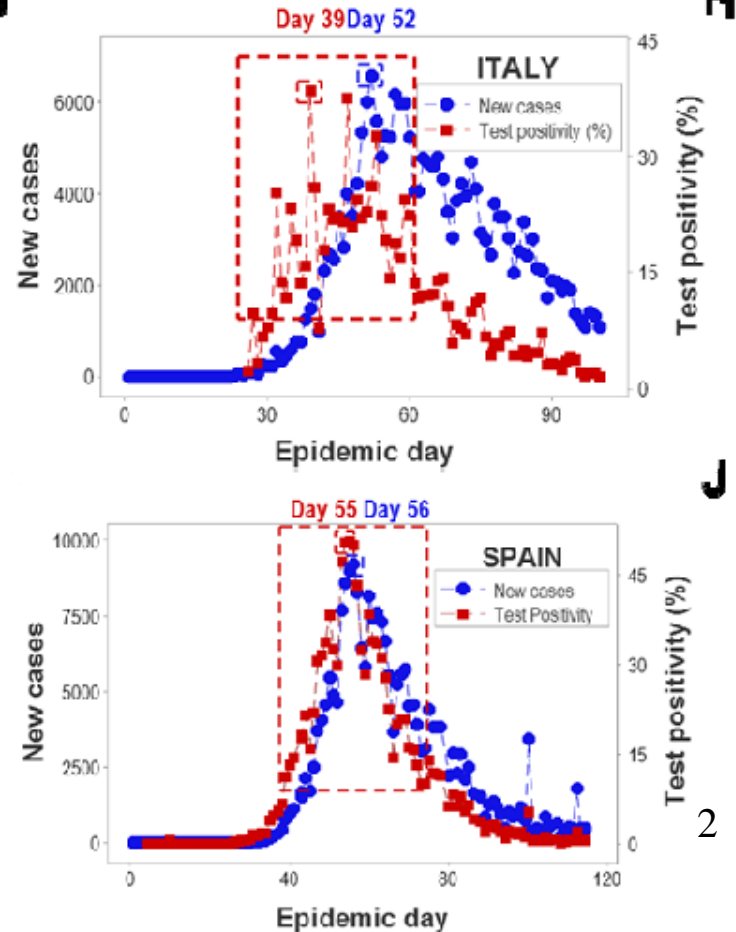

B

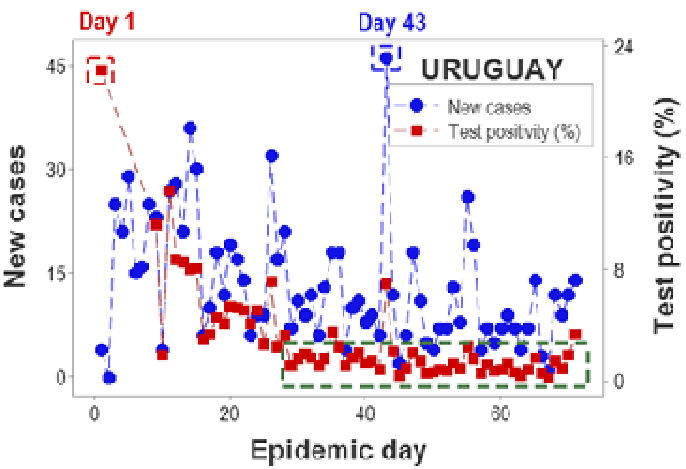

D

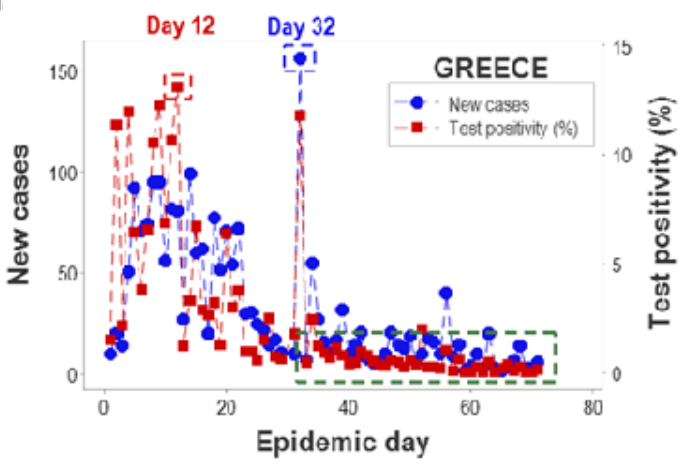

$F$

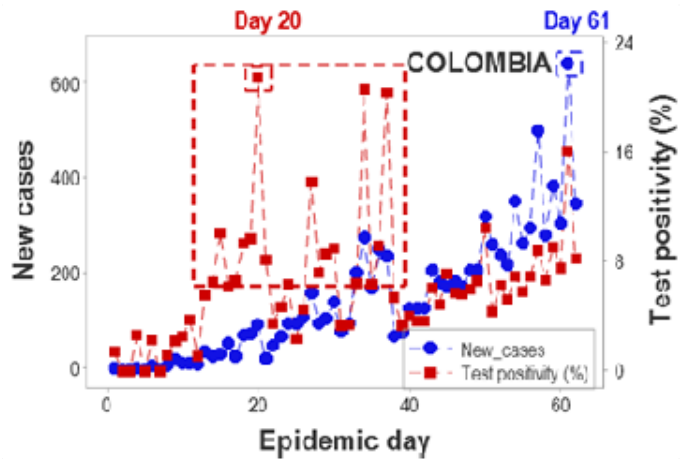

H
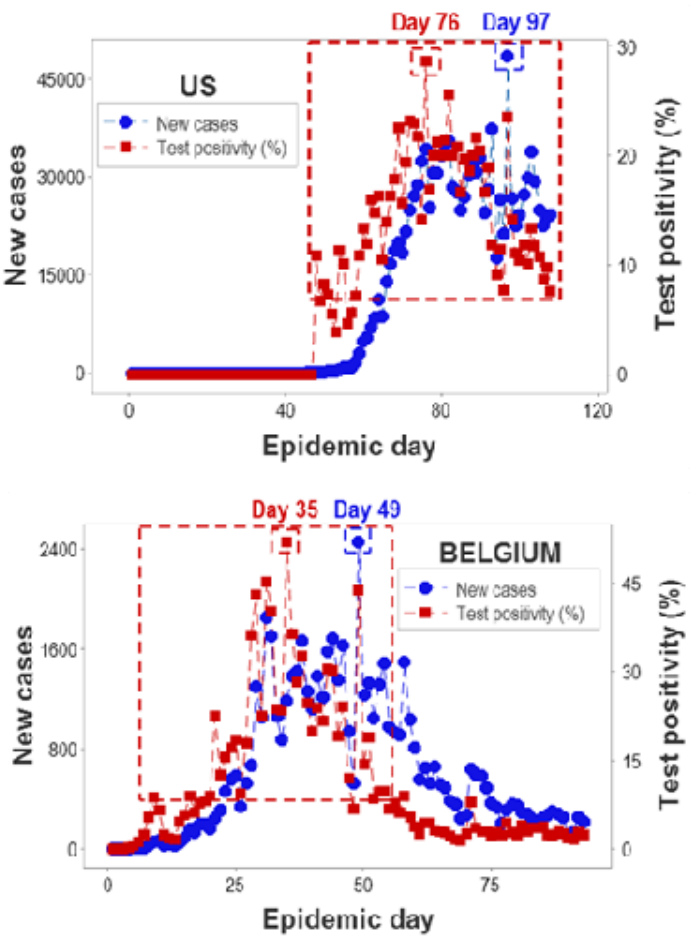
medRxiv preprint doi: https://doi.org/10.1101/2020.12.22.20223651; this version posted December 24, 2020. The copyright holder for this preprint (which was not certified by peer review) is the author/funder, who has granted medRxiv a license to display the preprint in perpetuity.

It is made available under a CC-BY-NC-ND 4.0 International license .

474 Fig. 1. Temporal relationships between the test positivity percentage and the number of

475 new cases. Two epidemic patterns were differentiated among10 countries: (i) epidemics that

476 revealed a rapid decrease in the test positivity (TP) percentage and, subsequently, displayed very

477 low $(<1 \%)$ TP values (green rectangles, A-D); and (ii) epidemics that reported either later TP

478 peaks, increasing percentages of the TP over two or more weeks, and/or TP percentages higher

479 than 5\% (red rectangles, E-J). In all ten countries investigated, the peak TP percentage occurred

480 earlier than the peak number of new cases. Source: Worldometer.

481

482 


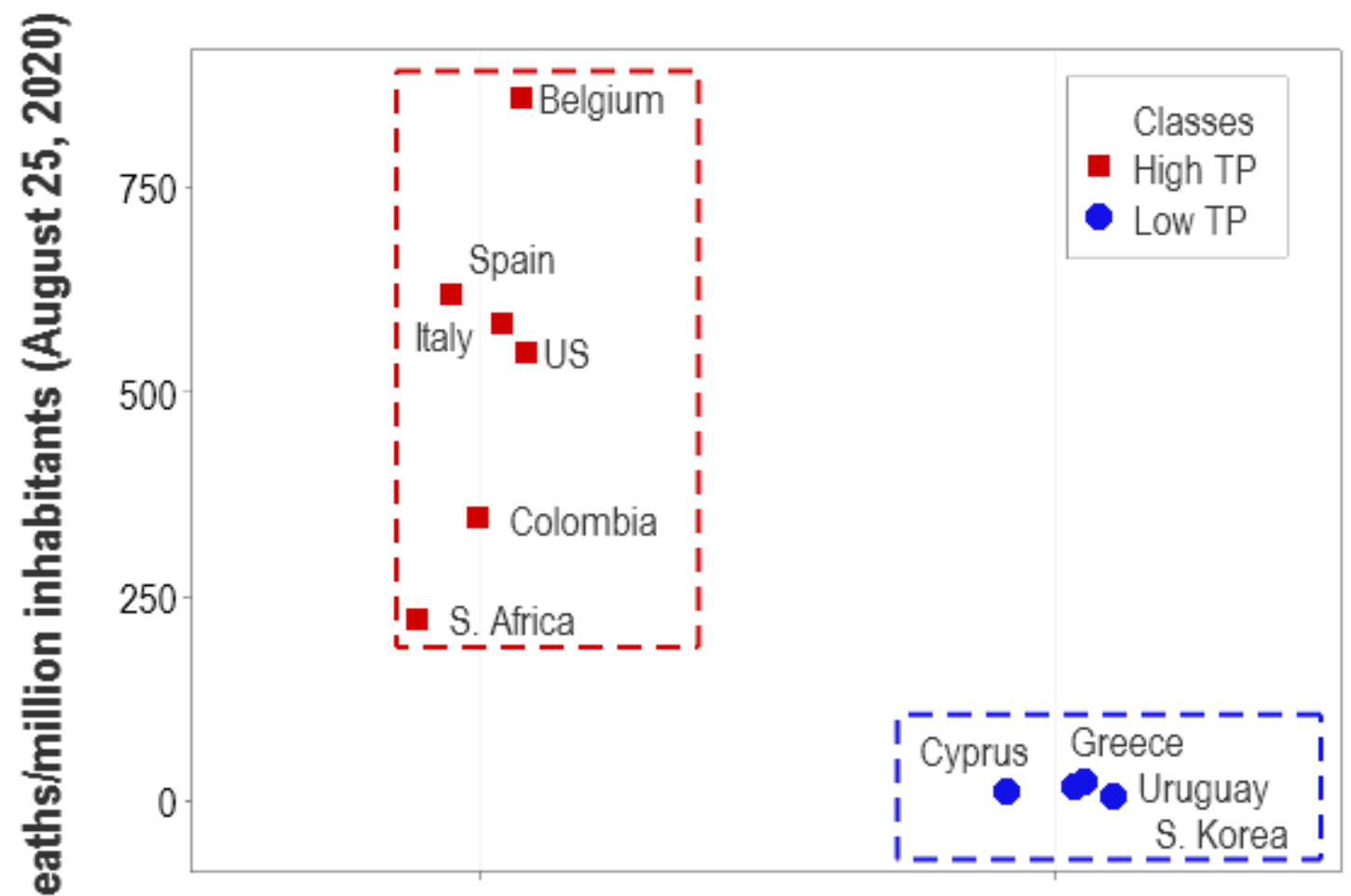

484 Fig. 2. Temporal relationships between test positivity percentage and deaths per million

485 inhabitants. By August 25, 2020 (at least four months into the epidemic), the group of countries 486 that, earlier, reported high (three-digit) test positivity percentages (high TP) showed at least 10 487 times more deaths per million inhabitants $(\mathrm{d} / \mathrm{mi})$ than countries that, earlier displayed low (two488 digit) TP percentages ( $p<0.02$, Mann-Whitney test). High and low TP countries revealed non489 overlapping data intervals (rectangles). Source: Worldometer. 

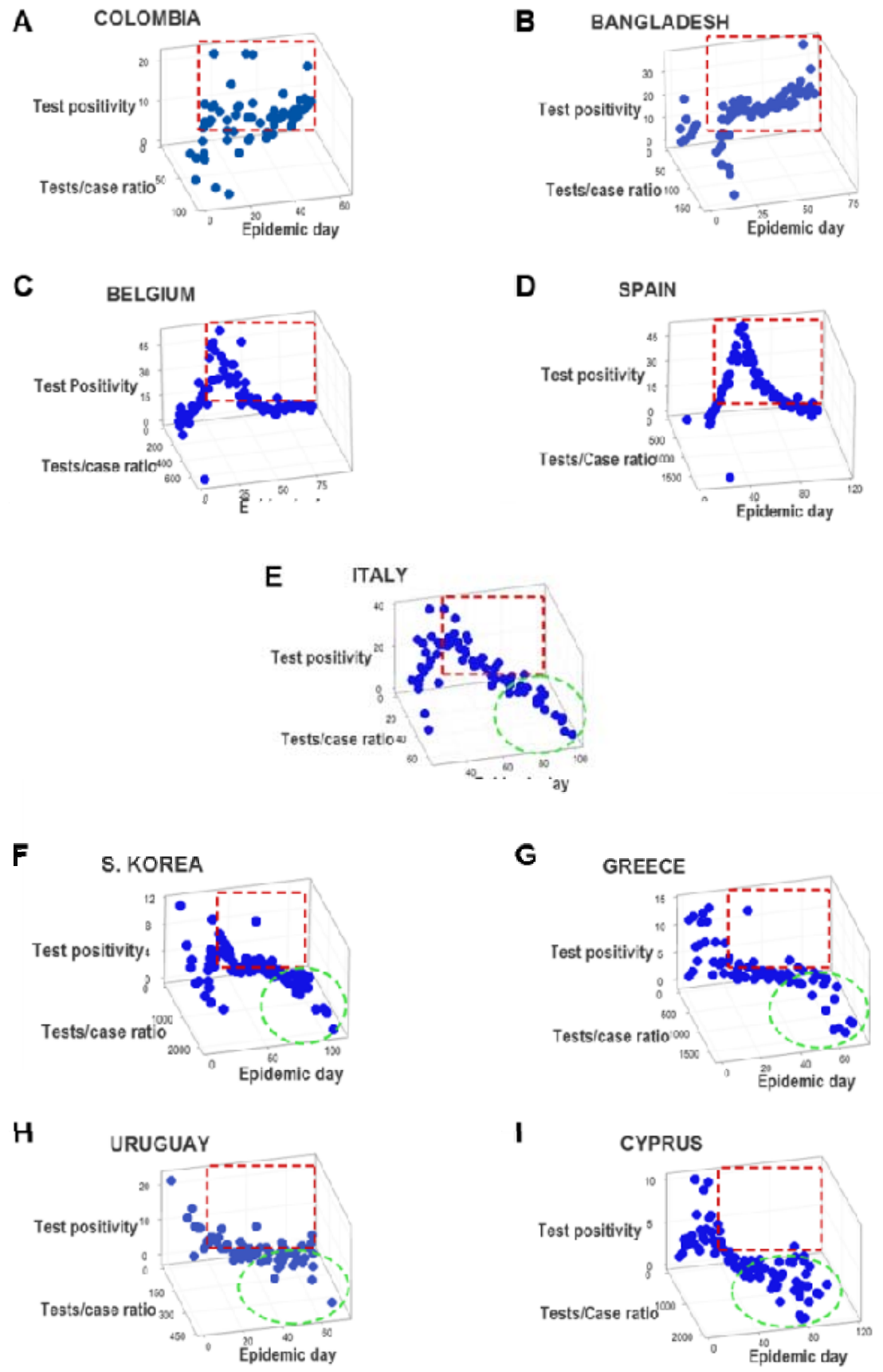

492

493

494

495

496

497

498

499

500

Fig. 3. Temporal relationships between test positivity and the tests/case ratio. The assessment of the tests/case ratio revealed more information when nine countries were investigated, which partially included the set reported in Fig. 1. Four countries showed high TP percentages but few or no high tests/case ratios (A-D). One country displayed a hybrid pattern, which was characterized by a few high TP percentages and a few high tests/case ratios (E). The remaining four countries predominantly exhibited high tests/case ratios (F-I). 

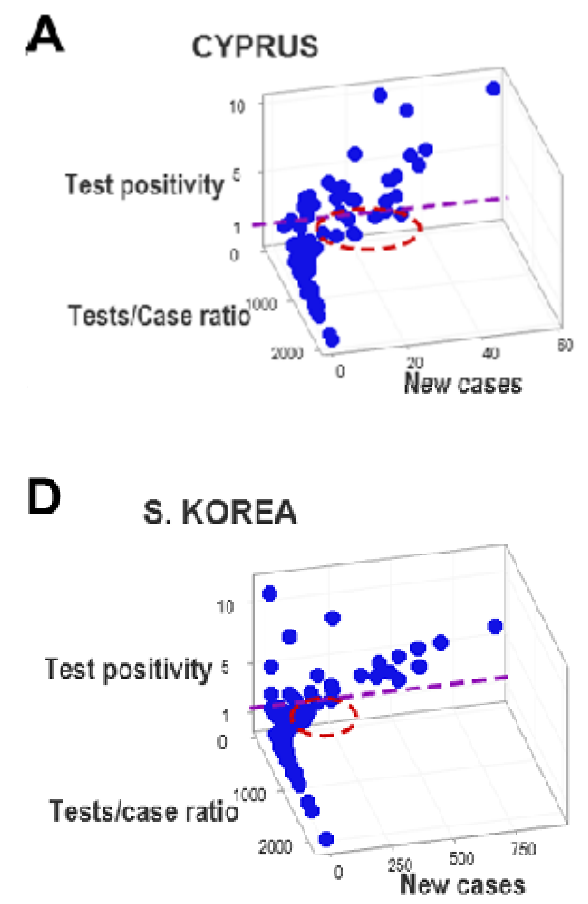
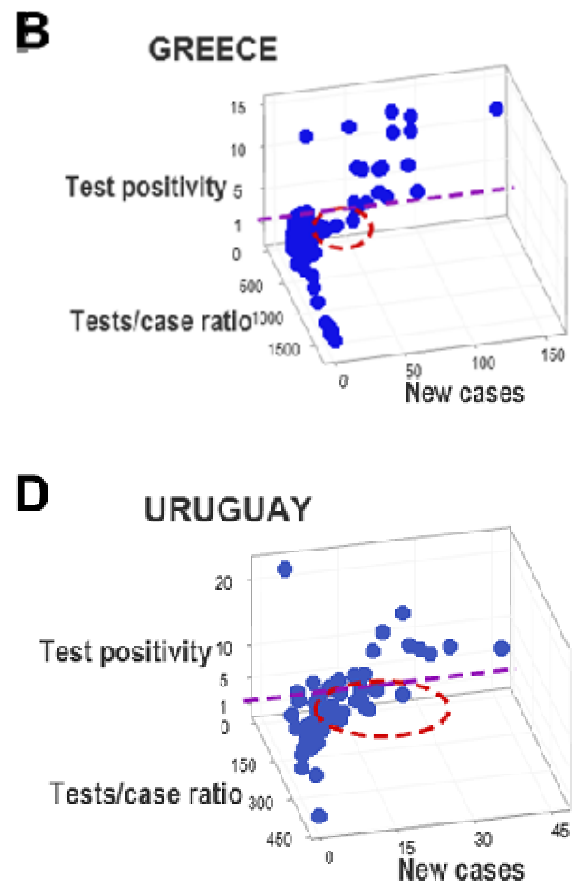

501

502

503

504

505

506

507

508

\section{Fig. 4. Pattern- vs. threshold-based evaluations of epidemic control measures. Four}

countries located in three continents showed new cases even when the percentage of test positivity (TP) was $<1 \%$ (ovals, A-D). Because new cases were observed over protracted (more than two-week long) periods of time, it is concluded that no numerical cutoff (e.g., TP $<5 \%$ ) indicates an epidemic is under control. In contrast, patterns -such as a perpendicular data inflection- promote inferences, regardless of any cutoff value. 


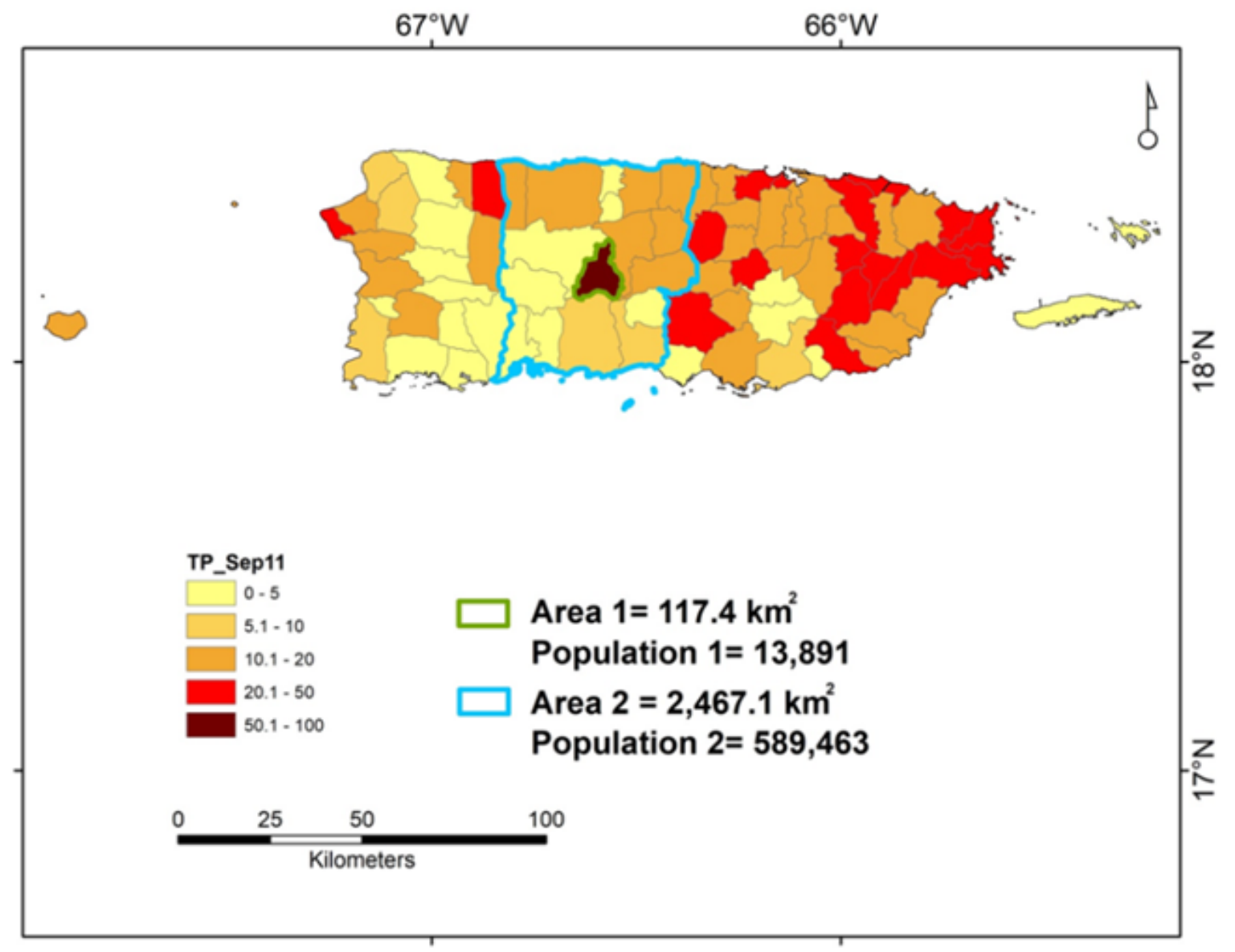

Fig. 5. Geo-epidemiologically specific, cost-benefit effective, differential testing. The test positivity (TP) percentages reported in all municipalities of Puerto Rico, on Sept 11, 2020, are depicted. Area 1 shows the municipality of Jayuya. Area 2 identifies a larger, surrounding region

514 that includes $\sim 42$ times more people and covers an area $\sim 8.5$ times larger than those of Jayuya.

515 Given Jayuya $+50 \% \mathrm{TP}$, a greater testing effort conducted in this municipality may yield large 516 benefits, which may also include the surrounding area (Area 2) and, indirectly, benefit the 517 western half of the island. Vice versa, keeping the same level of testing performed before may 518 lead to long-lasting, costly consequences: if the virus circulating within Jayuya reached the 519 surrounding area and the prevalence of COVID-19 became similar to the one affecting Jayuya 520 (which is estimated by test positivity), then a much larger number of people (up to 42 times 521 larger) could become infected, who would reside in an area 8.5 times larger, i.e., control would then be much harder, longer and costlier. 
medRxiv preprint doi: https://doi.org/10.1101/2020.12.22.20223651; this version posted December 24, 2020. The copyright holder for this preprint (which was not certified by peer review) is the author/funder, who has granted medRxiv a license to display the preprint in perpetuity.

It is made available under a CC-BY-NC-ND 4.0 International license .

A

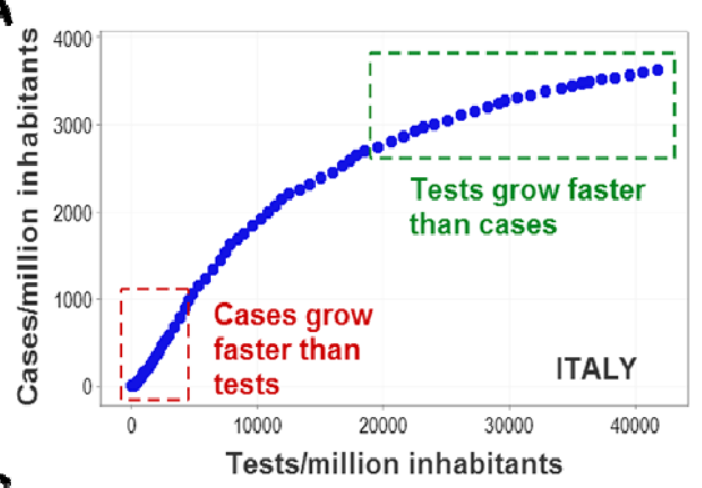

C

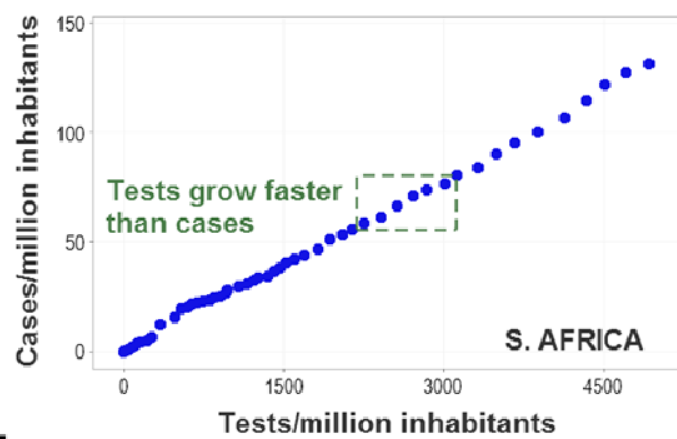

E

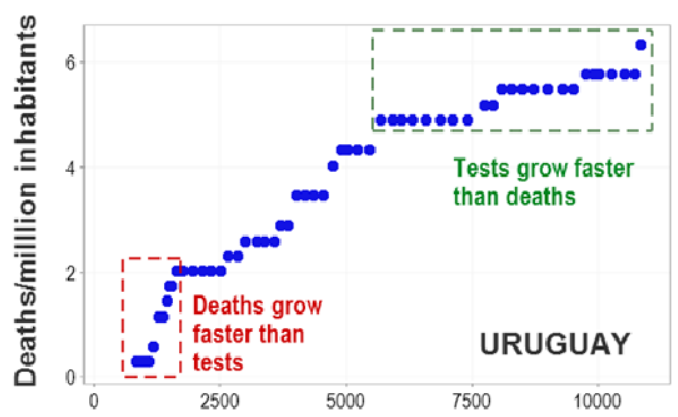

G

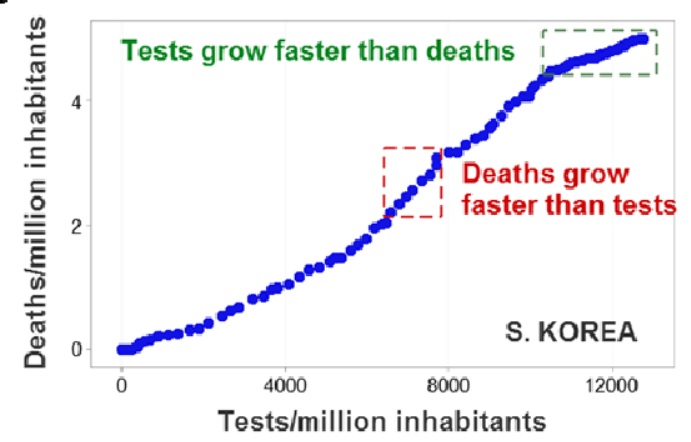

B

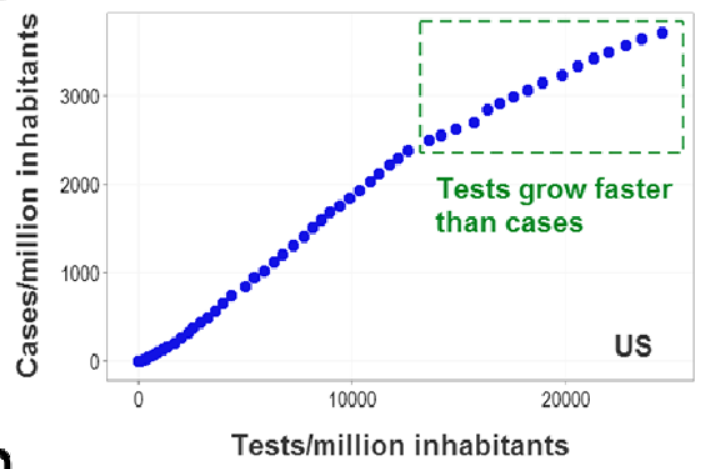

D

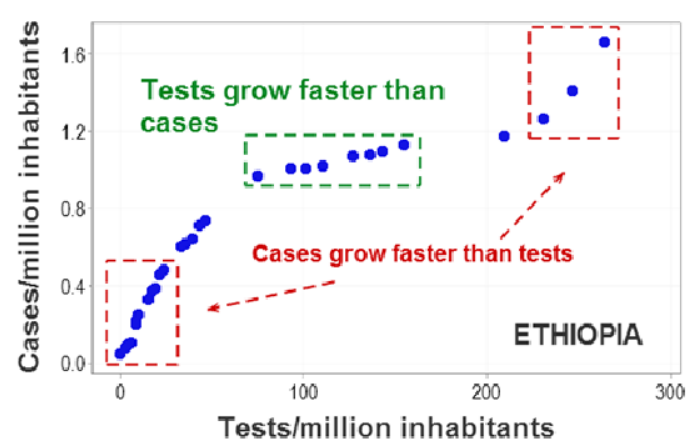

$F$

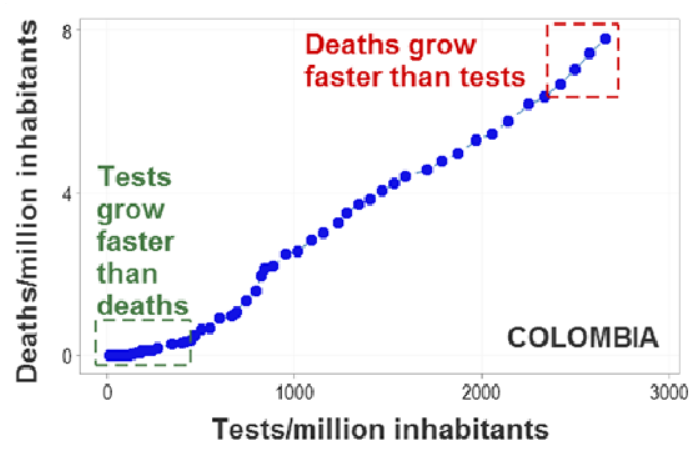

H

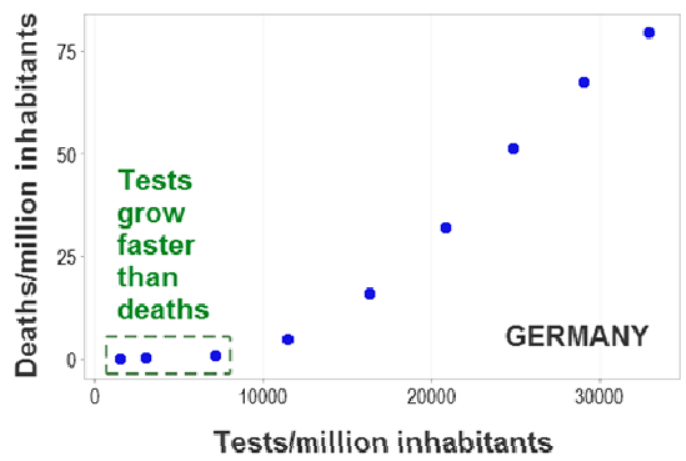

Fig. 6. Relationships between outcomes (non-fatal or fatal infections) and the number of tests/million inhabitants. Testing policies may be adjusted based on patterns generated by cases (A-D) and fatalities (E-H). When testing grows slower than cases or deaths (when the curvature approaches a vertical pattern), testing is likely to be insufficient or inadequate. 

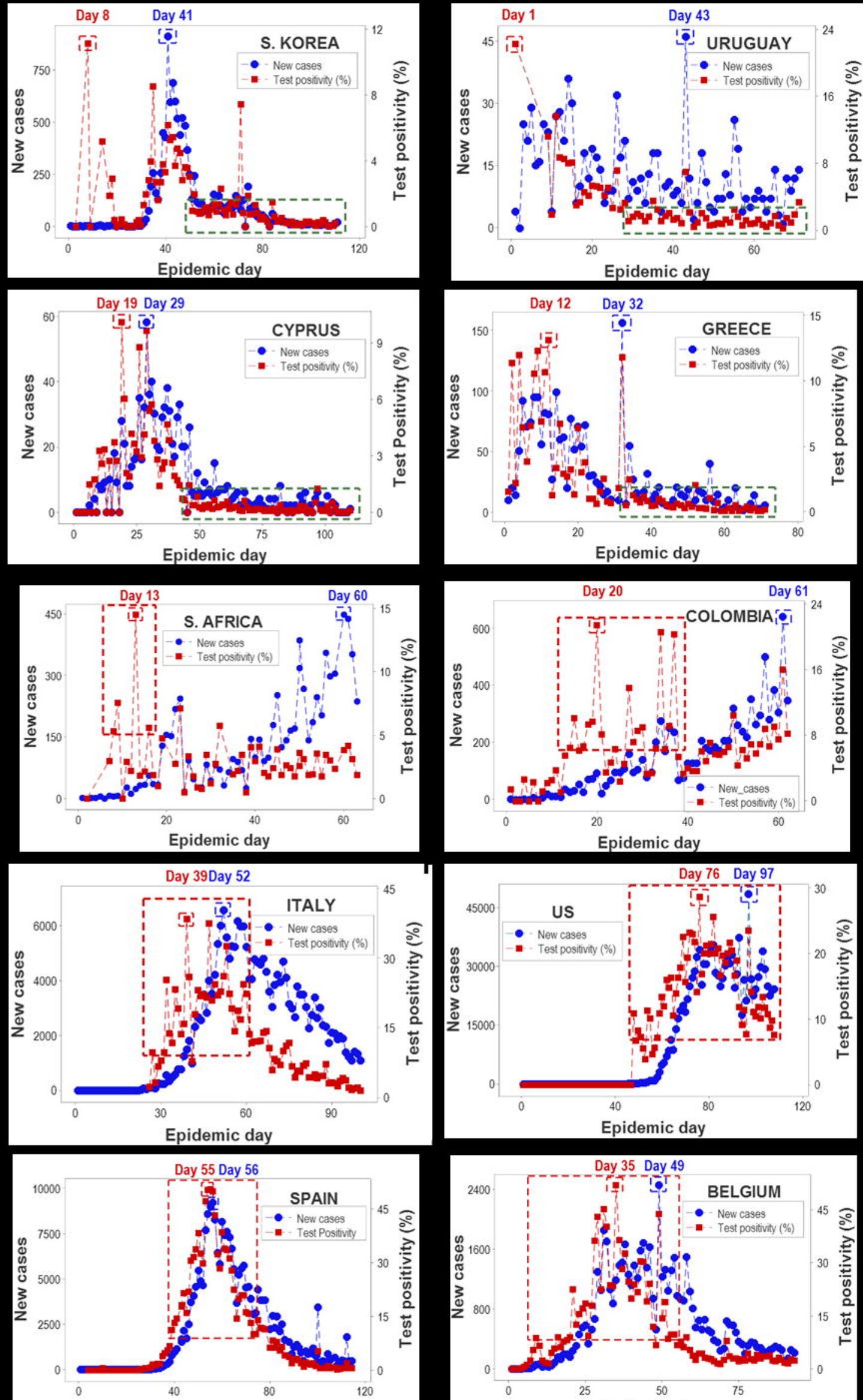

Epidemic day

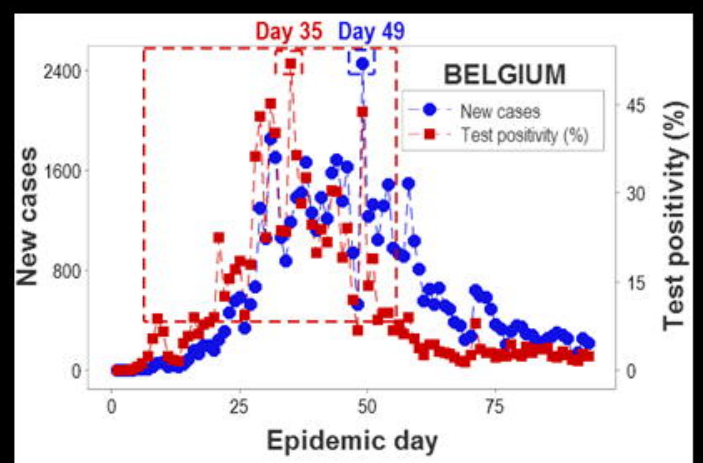




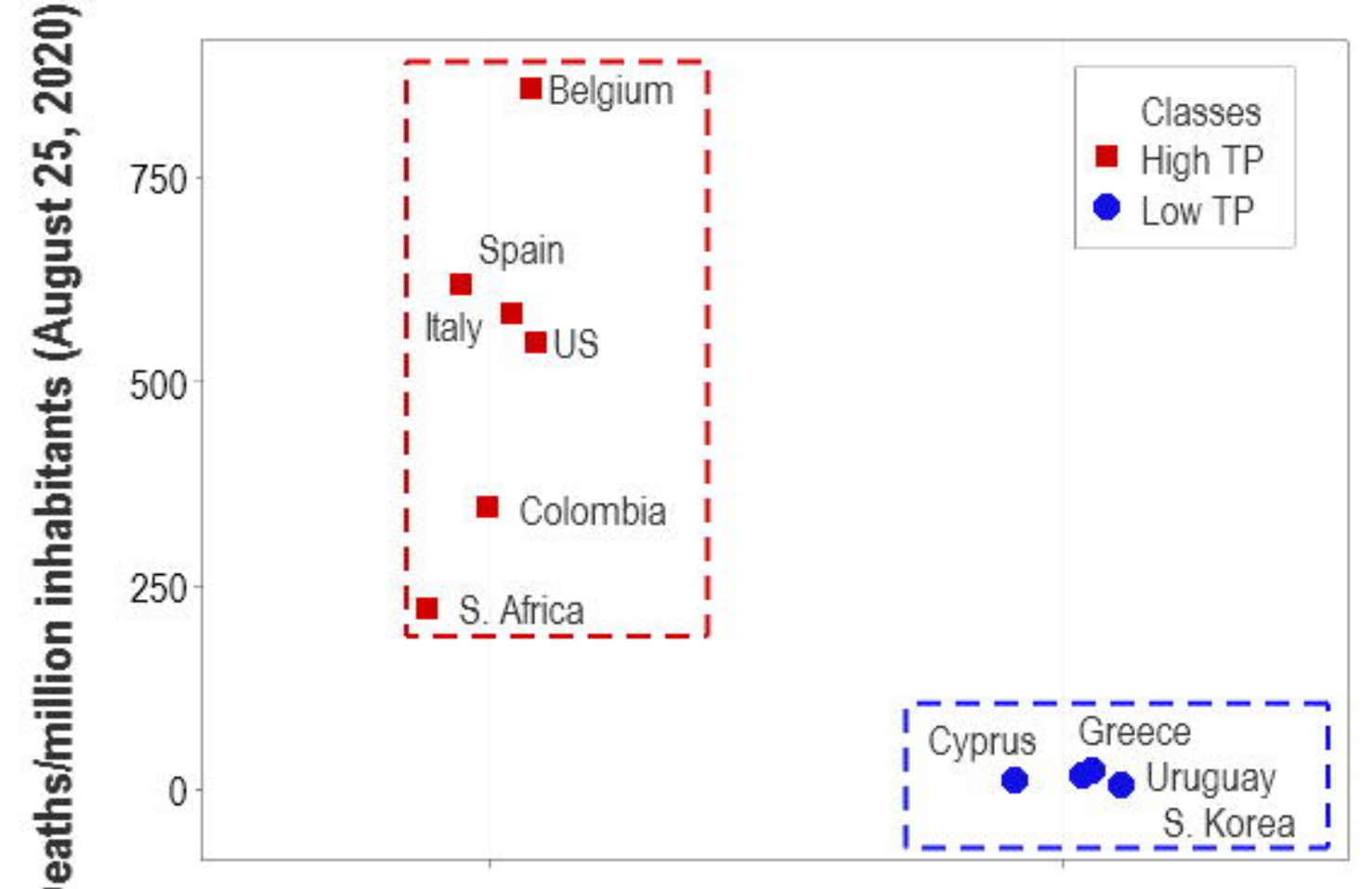


A

COLOMBIA

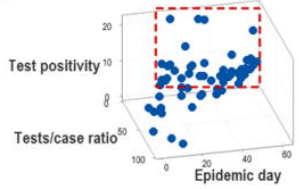

C

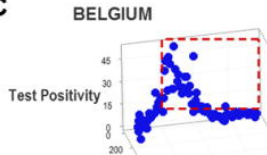

Tests/case ratio

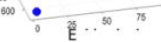

B BANGLADESH

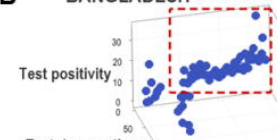

Tests/case ratio 100

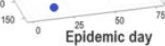

SPAIN

D

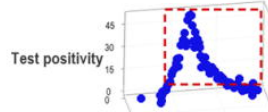

Tests/Case ratio 000

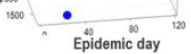

S. KOREA

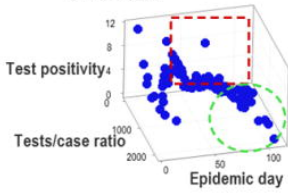

$\mathrm{H}$

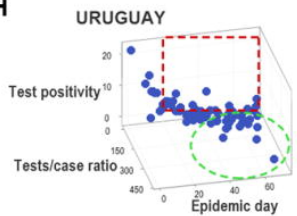

ITALY

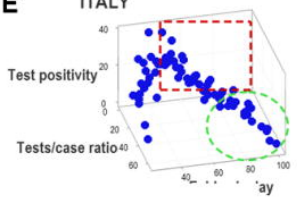

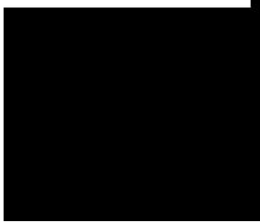

G

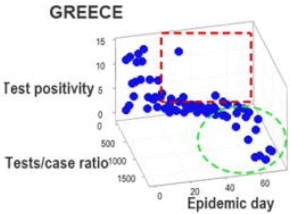

\section{CYPRUS}

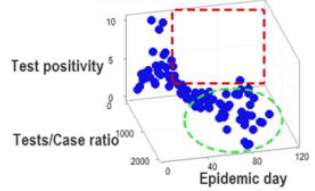


A

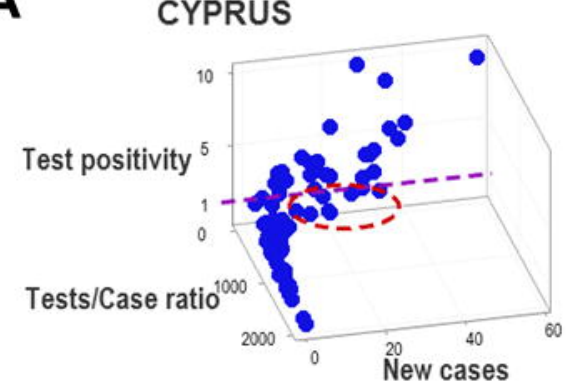

D

S. KOREA

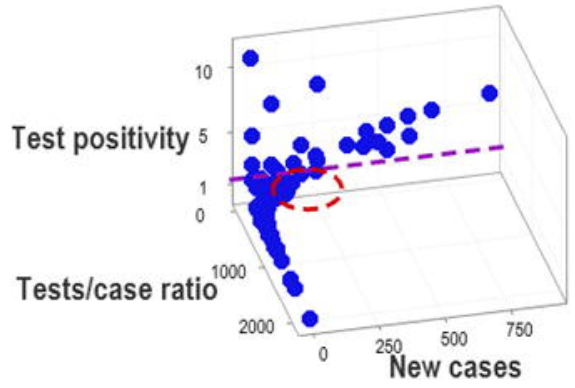

B GREECE

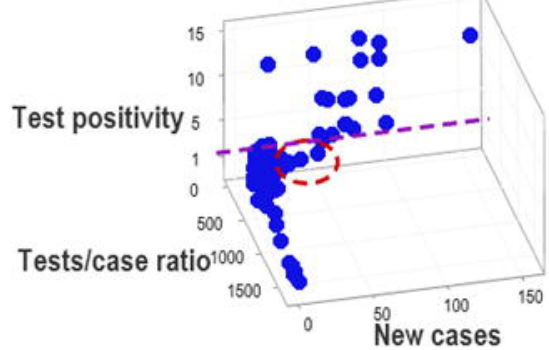

D

URUGUAY

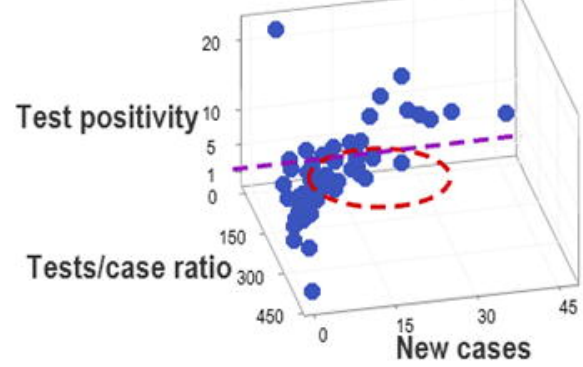




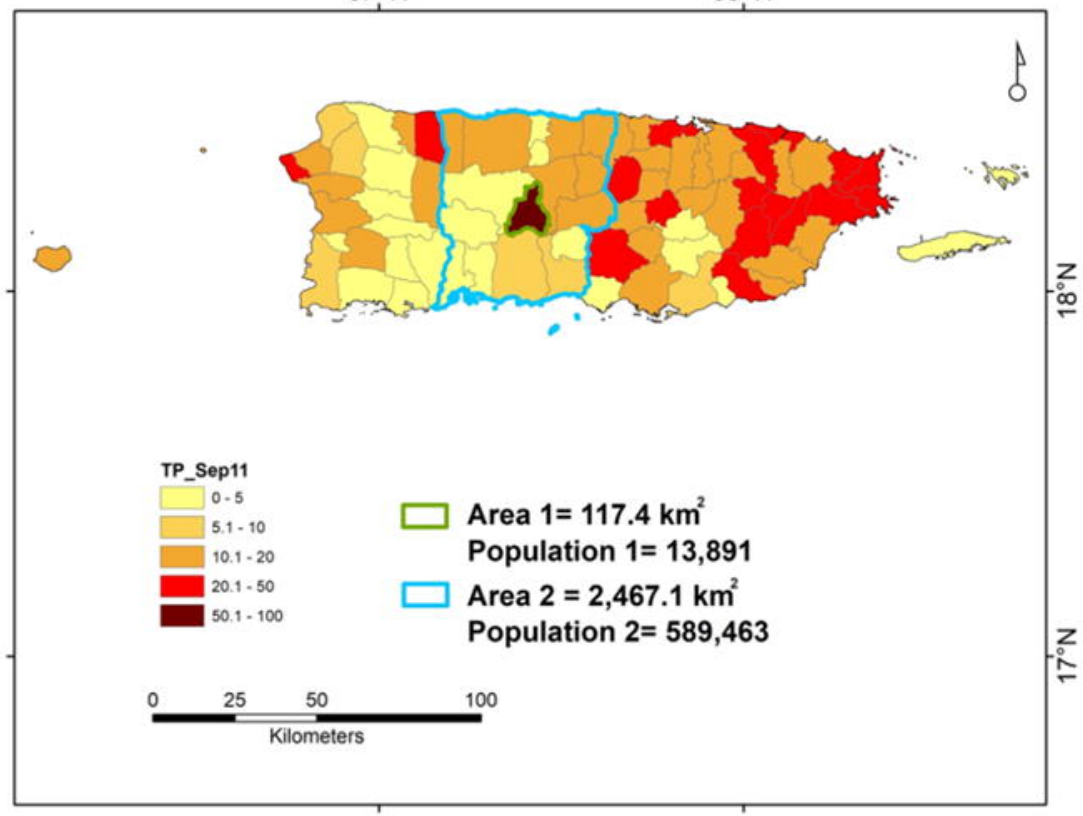



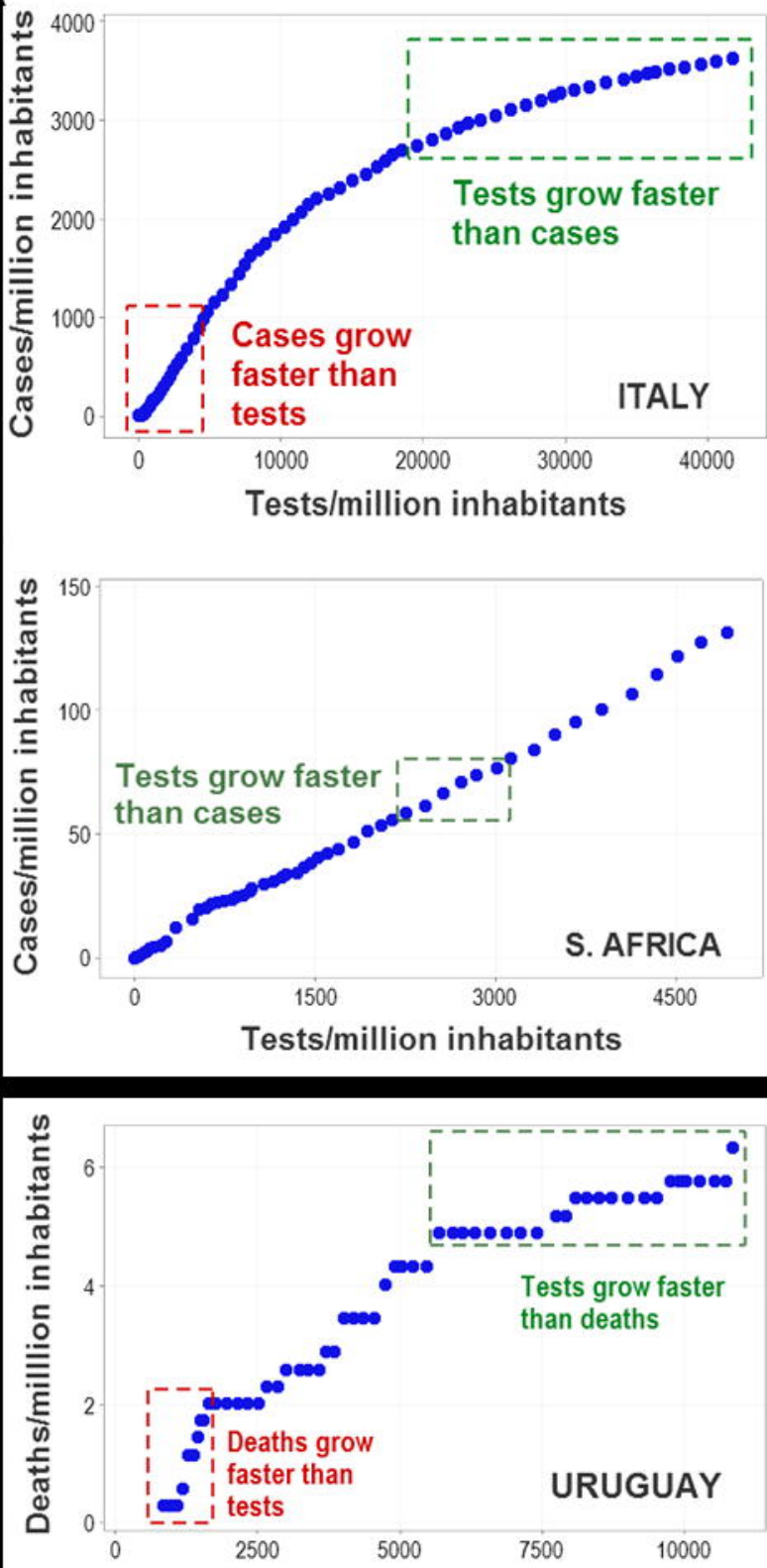

Tests/million inhabitants

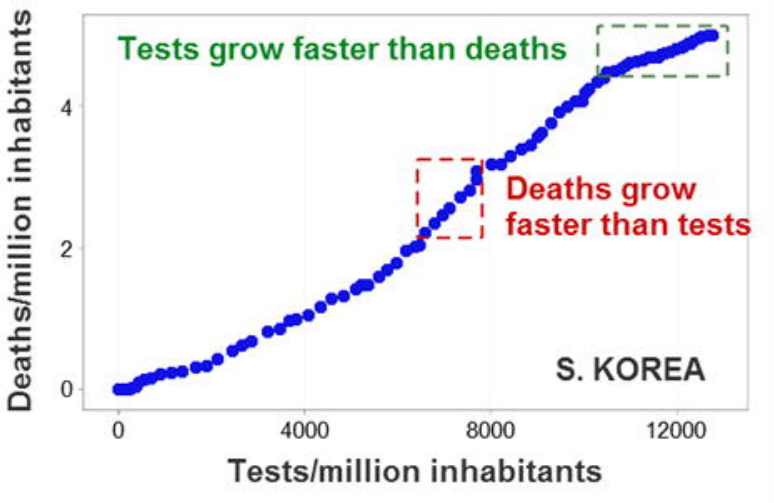

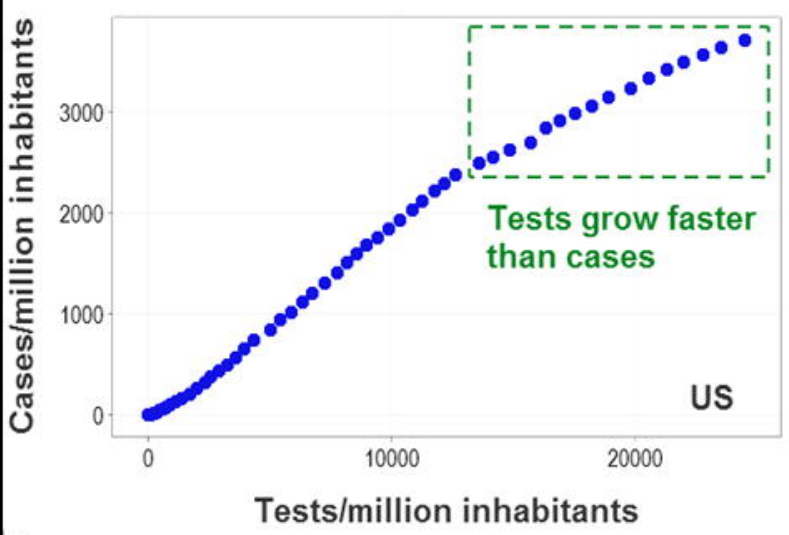
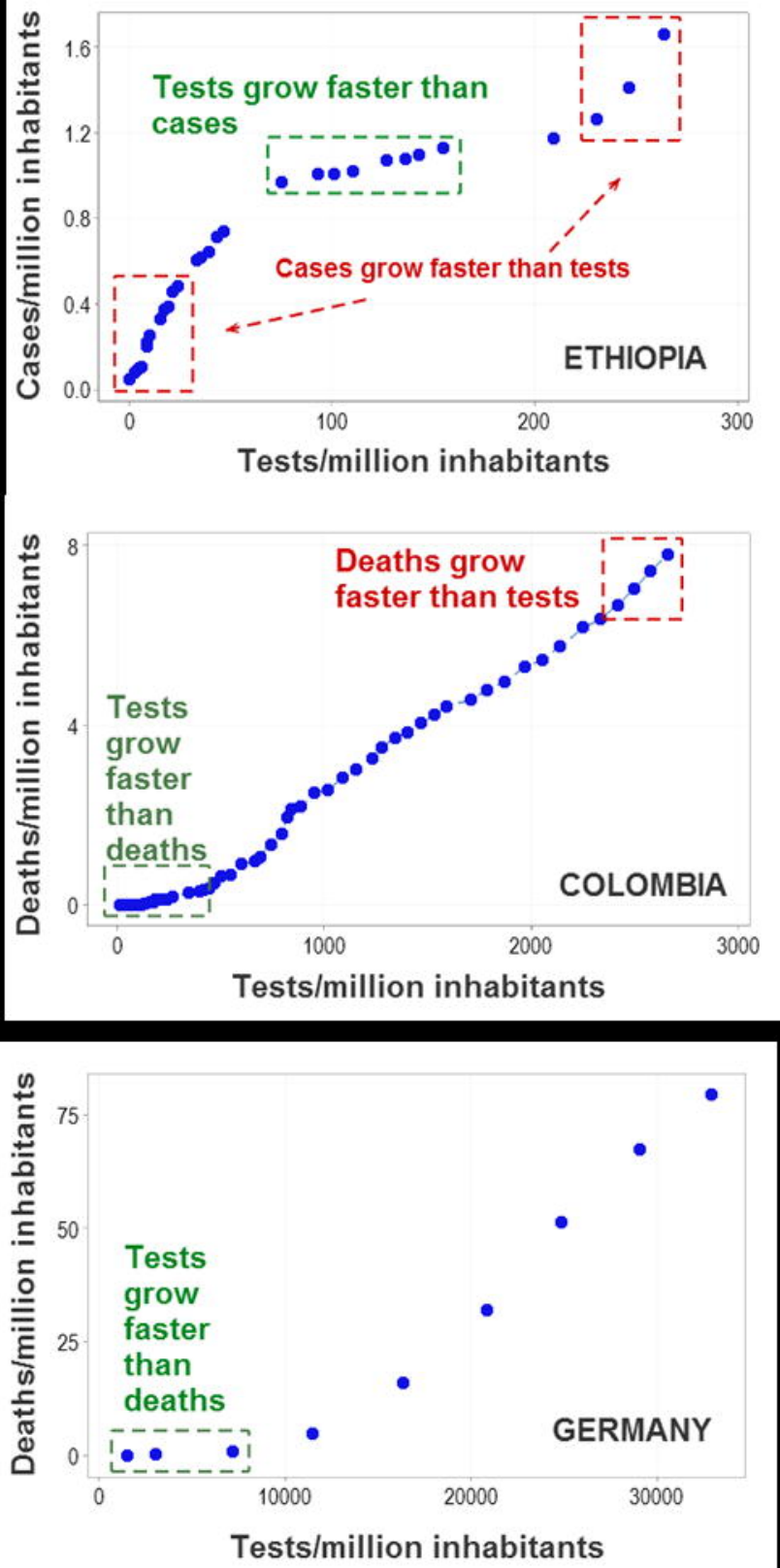